Portland State University

PDXScholar

$2-1-2012$

\title{
Developing an Integrated History and future of People on Earth (IHOPE)
}

\author{
Robert Costanza \\ Portland State University \\ Ida Kubiszewski \\ Portland State University \\ Scott Heckbert \\ Portland State University \\ Kathy A. Hibbard \\ Pacific Northwest National Laboratory \\ Sander Van der Leeuw \\ Arizona State University
}

See next page for additional authors

Follow this and additional works at: https://pdxscholar.library.pdx.edu/iss_pub

Part of the Sustainability Commons

Let us know how access to this document benefits you.

\section{Citation Details}

Costanza, R., S. van der Leeuw, K. Hibbard, S. Aulenbach, S. Brewer, M. Burek, S. Cornell, et al. 2012. Developing an Integrated History and future of People on Earth (IHOPE). Current Opinion in Environmental Sustainability 4 (1) (February): 106-114. doi:10.1016/j.cosust.2012.01.010.

This Post-Print is brought to you for free and open access. It has been accepted for inclusion in Institute for Sustainable Solutions Publications and Presentations by an authorized administrator of PDXScholar. Please contact us if we can make this document more accessible: pdxscholar@pdx.edu. 


\section{Authors}

Robert Costanza, Ida Kubiszewski, Scott Heckbert, Kathy A. Hibbard, Sander Van der Leeuw, Steve Aulenbach, Simon Brewer, Michael Burek, Sarah Cornell, Carole L. Crumley, Lisa J. Graumlich, Michelle Hegmon, Stephen T. Jackson, Paul Sinclair, Sverker Sörlin, W. L. Steffen, Carl Folke, J. A. Dearing, and Vernon Scarborough 


\section{Developing an Integrated History and future of People on Earth (IHOPE)}

Robert Costanza, Sander van der Leeuw, Kathy Hibbard, Steve Aulenbach, Simon Brewer, Michael Burek, Sarah Cornell, Carole Crumley, John Dearing, Carl Folke, Lisa Graumlich, Michelle Hegmon, Scott Heckbert, Stephen T. Jackson, Ida Kubiszewski, Vernon Scarborough, Paul Sinclair, Sverker Sörlin, and Will Steffen

Originally published in Costanza, R., S. van der Leeuw, K. Hibbard, S. Aulenbach, S. Brewer, M. Burek, S. Cornell, et al. 2012. Developing an Integrated History and future of People on Earth (IHOPE). Current Opinion in Environmental Sustainability 4 (1) (February): 106-114. doi:10.1016/j.cosust.2012.01.010.

This Article is brought to you for free and open access by the Portland State University Library at PDXScholar 


\section{Developing an Integrated History and future of People on Earth (IHOPE):}

Robert Costanza $^{\mathrm{a}}$, Sander van der Leeuw ${ }^{\mathrm{b}}$, Kathy Hibbard ${ }^{\mathrm{c}}$, Steve Aulenbach ${ }^{\mathrm{d}}$, Simon Brewer ${ }^{\mathrm{e}}$, Michael Burek $^{\mathrm{f}}$, Sarah Cornell ${ }^{\mathrm{g}}$, Carole Crumley ${ }^{\mathrm{g}}$, John Dearing ${ }^{\mathrm{h}}$, Carl Folke ${ }^{\mathrm{g}}$, Lisa Graumlich ${ }^{\mathrm{i}}$, Michelle Hegmon $^{\mathrm{b}}$, Scott Heckbert ${ }^{\mathrm{a}}$, , Stephen T. Jackson ${ }^{\mathrm{j}}$, Ida Kubiszewski ${ }^{\mathrm{a}}$, Vernon Scarborough ${ }^{\mathrm{k}}$, Paul Sinclair ${ }^{1}$, Sverker Sörlin ${ }^{\mathrm{g}, \mathrm{m}}$, and Will Steffen ${ }^{\mathrm{n}}$

a. Institute for Sustainable Solutions, Portland State University, Portland OR 97201

b. School of Sustainability \& School of Human Evolution and Social Change, Arizona State University Tempe, AZ 85287

c. Pacific Northwest National Laboratory, Richland, WA 99352 USA

d. NEON, Inc., 5340 Airport Boulevard, Boulder, CO 80301

e. Department of Geography, University of Utah, Salt Lake City, UT

f. Computational and Information Systems Laboratory, NCAR, Boulder, CO 80307

g. Stockholm Resilience Center, Stockholm University, 10691 Stockholm, Sweden

h. School of Geography, University of Southampton, Southampton, UK

i. College of the Environment, University of Washington, Seattle, WA 98195-5355

j. Department of Botany, University of Wyoming Laramie, WY 82071

k. Department of Anthropology, University of Cincinnati, Cincinnati, OH 45221

1. Department of Archeology and Ancient History, Uppsala University, Uppsala, Sweden

m. Division of History of Science and Technology, Royal Institute of Technology, Stockholm, Sweden

n. ANU Climate Change Institute, Australian National University, Canberra ACT 0200 Australia 


\section{Abstract}

The Integrated History and future of People of Earth (IHOPE) initiative is a global network of researchers and research projects with its International Program Office (IPO) now based at the Stockholm Resilience Center (SRC), Upsalla University, Arizona State University, Portland State University, and the Australian National University. Research linked to IHOPE demonstrates that Earth system changes in the past have been strongly associated with changes in the coupled human-environment system. IHOPE supports integrating knowledge and resources from the biophysical and the social sciences and the humanities to address analytical and interpretive issues associated with coupled human-earth system dynamics. This integration of human history and Earth system history is a timely and important task. Until recently, however, there have been few attempts at such integration.

IHOPE will create frameworks that can be used to help achieve this integration. The overarching goal is to produce a rich understanding of the relationships between environmental and human processes over the past millennia. IHOPE recognizes that one major challenge for reaching this goal is developing 'workable' terminology that can be accepted by scholars of all disciplines.

The specific objectives for IHOPE are to identify slow and rapidly moving features of complex social-ecological systems, on local to continental spatial scales, which induce resilience, stress, or collapse in linked systems of humans in nature. These objectives will be reached by exploring innovative ways of conducting inter and transdisciplinary science, including theory, case studies, and integrated modeling. Examples of projects underway to implement this initiative are briefly discussed.

\section{Brief History}

The idea for IHOPE emerged from a joint IGBP/IHDP (International Geosphere-Biosphere Program/International Human Dimensions Program) Planning meeting in Banff, Canada, in 2003. The following summer, a first planning meeting took place, aiming to kick the project off with a Dahlem Conference, which took place in June 2005 (convened by Costanza, Steffen, and Graumlich). In January 2006, a meeting took place in Stockholm to outline the Research Plan for the project (convened by Folke and Costanza), and in November of that year an informal meeting took place on the sidelines of the Earth System Science Partnership (ESSP) conference in Beijing to discuss the first steps towards implementation. A proposal was submitted (by Costanza, Graumlich and van der Leeuw) to the National Center for Ecological Analysis and Synthesis (NCEAS) to support a 3-yr working group, which was funded in 2007. That same year, the Dahlem book ('Sustainability or Collapse?' was published by MIT Press, and a first paper about the project was published in Ambio by its initiators ${ }^{2}$. A preliminary meeting of the 'US Southwest/Northern Mexico' team also took place at Arizona State University (ASU) in 2007.

2008 saw a series of scientific meetings. First a three-day meeting of the US Southwest/Northern Mexico project at the School of Advanced Research in Santa Fe, NM, followed by another 3-day meeting of the same group at the Santa Fe Institute in July of that year (both convened by van der Leeuw). In March, the project was presented for a wider academic audience in two dedicated panel sessions at the Resilience 2008 conference in Stockholm organized by Costanza, Sörlin and Crumley. In April, a first meeting of the Maya project was held at the Society of American Anthropology in Vancouver (convened by Scarborough and van der Leeuw). In September, the first of three meetings at the National Center for Ecological Analysis and Synthesis (NCEAS) were held assembling the larger IHOPE group (convened by Costanza, Graumlich and van der Leeuw).

These meetings were followed in 2009 by a three-day meeting of the Maya group (convened by Scarborough and van der Leeuw) at the School for Advanced Research, and the second NCEAS meeting in September (convened by Costanza, Graumlich and van der Leeuw). The project was presented at the Past Global Changes (PAGES) Young Scholars meeting in Corvallis in July (by van der Leeuw and Dearing)

2010 finally saw the formal establishment of the project with a number of events. First among these was the creation of the International Project Office at the Stockholm Resilience Center. ASU has offered to fulfill the function of Regional Office for the Americas. The same year, the project was accepted as a jointly (with IGBP) sponsored project by IHDP, and various members of the project team published a number of papers that emerged from the project (see bibliography, below). A series of meetings were held both in Stockholm and in the US, while the third meeting of the IHOPE working group at NCEAS was held in September. 
In August, 2011 the first formal meeting of the IHOPE Scientific Steering Committee was held at Uppsala University in Sweden, (hosted by Sinclair). At this meeting it was decided to have a distributed International Program Office (IPO) with major nodes at Uppsala University (Sweden), Stockholm Resilience Centre (Sweden), Arizona State University (US), Portland State University (US), and the Australian National University (Australia).

\section{Long Term Goals}

The IHOPE project has identified three long-term goals ${ }^{3}$ :

1. Map the Earth's integrated record of biophysical and human system changes over past millennia. Higher temporal and spatial resolution will be possible in more recent periods of analyses (e.g., 100-2000 years before present (YBP)). The range for longer-term analyses will depend on the region. For example, Australian history might include the past 60,000 years, and in southern Europe, the past 20,000 years could cover colonization since the Last Glacial Maximum (LGM).

2. Test human-environment system models against the integrated history to better understand the socio-ecological dynamics of human history. How well do various models of the relationships between climate, agriculture, technology, disease, language, culture, war and other variables explain the historical patterns of human settlement, population, energy use and Earth system cycles described by global biogeochemistry?

3. Project, with more confidence and skill, options for the future of humanity and Earth systems. These projections will be based on models that have been tested against the integrated history and with contributions from the full range of participants.

Consistent with these long-term goals, three overarching questions have been identified for the IHOPE project.

1. What are the key socio-ecological interactions from an integrated history that provide insight into future options?

2. What are the complex and multiple interacting processes and scales that steer the emergence, resilience, sustainability or collapse of coupled socio-ecological systems? A part of this question is to understand, derive and quantify the relative contributions of humans as causal agents.

3. What is needed to evaluate alternative explanatory frameworks, specific explanations and models (including complex systems models) against observations of highly variable quality and coverage?

\section{Framework and Methods}

A major goal of IHOPE is to learn from the past to inform future possibilities and help create a better future. Our basic framework for accomplishing this involves integrating theory, comparative studies and socioecological modeling across a range of spatial and temporal scales (Table 1). There have already have been efforts published which deal with mapping human induced changes over long time periods. These include mapped time 
series of population and land use changes, sometimes for the whole Holocene $e^{4,5,6,7,8}$. We will build on these and other efforts at producing integrated historical data bases.

Case studies in the Americas, Europe, Australia, Africa, etc. (see below), along with interregional and global scale studies will implement this framework. The case studies listed are not exhaustive, but are some of the ones currently under way. We ultimately expect case studies in all regions.

Table 1. Possible Ways to Learn From the Past

Geographic Areas

\begin{tabular}{|l|l|l|l|l|l|l|l|}
\hline Approaches & Americas & Europe & Australia & Asia & Africa & $\begin{array}{l}\text { Inter- } \\
\text { regional }\end{array}$ & Global \\
\hline Theory & & & & & & & \\
\hline $\begin{array}{l}\text { Comparative } \\
\text { Studies }\end{array}$ & & & & & & & \\
\hline $\begin{array}{l}\text { Integrated } \\
\text { Modeling }\end{array}$ & & & & & & & \\
\hline
\end{tabular}

Clearly, all these transverse (horizontal) activities are based on the bringing together of data in the different geographic areas (specified vertically), using theory, comparative studies, and integrated modeling.

The application of these practices provides the traceability and transparency required for academic review of IHOPE results by the international community. The rigorous application of these practices will greatly improve interoperability within and between communities of practice that will use IHOPE products now and in the future.

\section{Theory}

The challenges of modeling future socio-ecological states numerically suggest that qualitative understanding of system behavior should be further developed. The objective here is to identify and develop general principles of socio-ecological system behavior, supported by empirical evidence drawn from long records of regional environmental change. A few are deduced from historical case studies. But for others, we can take principles (often aphorisms) from theoretical ecology and complexity science and test their validity in the real world by comparison with historical records. Past records not only provide longer timescales than are conventionally available for observations, but also provide a larger array of socio-ecological systems than currently exist.

As a basic starting point, here are some principles drawn from the literature and discussions at IHOPE meetings that could be tested (or tested further) with archaeological/palaeoecological/historical records. The bullet points note variants on each theme, further explanations and implications.

\section{Societal dynamics}

- Complexity in social systems is the long-term paradox of problem solving ${ }^{9}$

- Short term and self-interest can overwhelm long term and wider interests via social traps and dilemmas ${ }^{10,11}$.

- Heterarchically (as opposed to hierarchically) structured societies provide more resilience ${ }^{12}$

\section{Ecosystem dynamics}

- Increased complexity begets stability

- System resilience is controlled by slow-long processes

- Self-organized systems tend towards more resilient networks

- Naturally evolved systems can reach critical states where they respond disproportionately to perturbations from outside the set of boundary conditions within which the system evolved

- Variability increases before threshold change 
- Systems slow down in advance of abrupt change

\section{Coupled socio-ecological dynamics}

- Human actions tend to increase system sensitivity, decrease interconnectivity and increase predictability

- Managed systems tend to shift the risk spectrum towards more frequent, higher magnitude events

- Convergent trajectories within an socio-ecological system tend to increase vulnerability

- Increased spatial homogeneity leads to lower resilience

- Sustainability equates to sub-optimal efficiency

- Diversity of both species and of practice in socio-ecological systems increases resilience

\section{Comparative studies}

These studies look at the dynamics of societies at different scales and under different environmental circumstances. They are presented here in a continuum from the least aggregated and most mobile to the most aggregated and sedentary. The purpose of these studies is (1) to improve our understanding of the dynamics involved in the emergence and functioning of the systems, and (2) to identify a level of abstraction at which these dynamics can be described and understood in similar terms for each one, so that a truly comparative study becomes possible.

\section{Australia}

Key participants: A. Williams, M. Smith, L. Robin, W. Steffen, C. Turney (All ANU)

The first part of the project is centered on a synthesis of a very large amount of archaeological and climatic data for the Australian continent, and aims to tease out aspects of the human-environment relationship in Australia's pre-European past. A good example of this work is a recent paper: Hunter-Gatherer Response to Late Holocene Climatic Variability in Northern and Central Australia ${ }^{13}$. The paper finds that over the past 2000 years changes in the archaeological signature correlate reasonably well with transitions in the ENSO mean state between generally wetter and drier conditions.

The second part of the project (Life in a Land of Uncertain Extremes), is focused on the variability of the Australian environment at a range of time scales. The central research questions were: (i) How does a calendar driven by 'pulses' dependent on temperature, water, fire, vegetation and other life-sustaining resources, not simply annual cycles around the sun, shape biological, social and economic activity? (ii) How has Australia come to terms with the limits imposed by 'pulses' and extreme events in the past? The primary product of the project was a mono$\operatorname{graph}^{14}$.

In the third part of the project, the environmental dynamics will be confronted with the societal dynamics and models constructed that will help us develop a more dynamic understanding of long-term socio-environmental change in this environment. This new initiative is designed to be a contribution to the "future" timeframe of IHOPE. The aim of the project is to develop models that can simulate the coupled biophysical-social-economic cycles of the human-earth system. The initial workshop will address three simple but profound questions:

- What are the limits of quantitative description that models of the human-earth system can aspire to?

- Can we identify the essential process ingredients that models of the human-earth system must include?

- What is the optimum or the minimum spatial, temporal or sectoral resolution necessary to capture these processes in global and national scale models?

\section{US Southwest / Northern Mexico}

Key participants: D. Abbott, J. M. Anderies, M. Hegmon, K. Kintigh, A. Kinzig, B. Nelson, M. Nelson, K. Spielmann (all at ASU)

Over the past 3,000 years, the region has seen a succession of very different adaptations to extreme climatic circumstances. This group has been working together for decades to study different cultural responses to environmental change, based on a comparative study of six sub-regions in the area, which underwent very similar changes in climate, but had different social and environmental resources to cope with these. The project benefits from long tree-ring sequences that allows detailed reconstructions of fluctuations in annual average precipitation and temperature and the assignment of precise dates to the archaeological evidence. In addition, the project has devel- 
oped dynamic (multi-agent) models of social-environmental interaction over thousands of years and a sophisticated historical GIS database. By comparing how the region's extreme environmental circumstances have been managed by different societies over the last 10,000 years, the group can focus on distinguishing cultural and economic factors from environmental conditions. Funding for this Core Project has come from the US National Science Foundation and Arizona State University.

\section{Yucatan}

Key participants: Vernon Scarborough (University of Cincinnati), Arlen and Diane Chase (Florida Central University), Keith Prufer (University of New Mexico), Jeremy Sabloff (Santa Fe Institute), Joseph Tainter (Utah State University), Fred Valdezs (University of Texas), Rodrigo Liendo (Universidad Nacional Autonoma de Mexico), David Lentz (University of Cincinnati), Scott Fedick (University of California), Joel Gunn (University of North Carolina), Nicholas Dunning (University of Cincinnati), Gyles Iannone, (Trent University), Scott Heckbert (Portland State University)

Home to the Maya civilization, the Yucatan Peninsula is being studied from 1000 BCE to 1000 CE. The chronology is well-established through the presence of stelae with calendar dates. The region is important to the Earth system because such tropical wet-dry forests hold half of the planet's biodiversity. The region's historical ecology can help us understand how to maintain these ecosystems and the humans that live there. The Mayanists, each of whom is involved in an independent, large-scale project, demonstrate what can be accomplished at the regional scale when investigators agree to collaborate. In particular, eight 'hotspots' have been selected in which the environmental and archaeological data together permit to outline the long-tem socio-environmental dynamics over the roughly 1500 years of Maya occupation of these areas. Comparing the local environmental differences (relief, regional climate, resources, water, etc.) and the differences in social organization enable us to identify how these different factors have contributed to the individual trajectories of these hotspots under similar conditions of global environmental change. This Maya example also permits exploration of teleconnections with other regions, biomes, and continents. Because the European group (see below) is studying the same period (1000 BCE to $1000 \mathrm{CE}$ ), comparisons with societies surrounding the Atlantic Basin (e.g., Western Europe, North and Middle America, including the Yucatan Peninsula) are expected to allow exploration of deviation amplifying and deviation counteracting conditions at regional, oceanic, continental and global scales. An intriguing example would be to contrast conditions around AD 900 that contributed to the decline of centralized power in southern Yucatan with those implicated in the rise of European power in the post-Migration period. A joint research proposal to the US NSF is being drafted.

\section{Europe}

Key participants: I. Ralston (University of Edinburgh), V. Guichard (Bibracte), C. Crumley (Stockholm Resilience Center), J. Dearing (University of Southampton), S.E. van der Leeuw (Arizona State University), I. Jouffroy (Université de Franche Comté, Besançon), P. Sinclair, F. Herschend, S. Fischer, H. Lejdegård, (all Uppsala University), K. Holmgren (Stockholm University), V. Caracuta, G. Fiorentino (both University of Salento), S. Kane (Oberlin College)

This subproject is new and less well developed, but it draws on one of the most detailed human and environmental histories in the world. With special attention to climate fluctuations with a periodicity of hundreds of years, the group will take a critical perspective on the intervals of rapid environmental change and social reorganization before (ca. 450 BC) and after (ca. 500 AD) a stable warm event coincident with the expansion of Rome. The geographical extent of the study is E-W from the Urals to the Atlantic façade and N-S from southern Scandinavia to North Africa. Focusing on three regions (southern Scandinavia, central to southern France by way of the Rhône corridor, and southern Italy), the network will, as in the Yucatan, connect many independent research campaigns. For example, the Rhône Corridor region will collate findings from major projects that have been underway for decades in the regions of Bourges, Burgundy, Annecy, and the Midi. The Corridor itself, running N-S between the Alpine and Central massifs, crosses the major ecotone between the West European subtropical and temperate climate regimes and records historic temperature and precipitation shifts. For millennia, the Corridor has been the major N-S trade, military, and migration route across the western European continent.

Carole Crumley, Steve Jackson, and Simon Brewer are exploring potential interactions among climate change, vegetation cover, and cultural activities and practices during the Period $1000 \mathrm{BCE}-1000 \mathrm{CE}$ in Europe and 
western Asia. We are compiling paleoclimate records, vegetation records, land-cover simulations, and archeological and documentary data to produce a master chronology for comparison, particularly of climate changes and cultural benchmarks. Our working hypothesis is that the peak warm period coincided with flattening of the latitudinal temperature and moisture gradients in Europe, facilitating widespread and intensive wheat cultivation. We postulate that these gradients steepened during the migration period, resulting in increased difficulties in cultivation at the margins of the Empire. We will test this hypothesis and formulate other hypotheses as the compilations continue. We anticipate one paper next spring that presents the climate chronology and cultural chronology and compares them to discuss potential relationships.

\section{Modeling}

Under this transverse theme, we expect to be developing a series of integrated models for each of the different case studies that function as dynamic descriptions of the life cycle of these societies. These models will draw heavily upon the theoretical work mentioned above, as well as the case study descriptions. They will be structurally designed in ways that allow the dynamics to be compared across the cases studied.

One current activity of the project is building an integrated dynamic systems/agent-based model of the Maya civilization. The model includes the dynamics of the biophysical system - climate, water, vegetation, primary production etc. integrated with the human system - demography, settlements, agriculture, trade, technology, institutions, etc. to replicate the dynamics of the civilization over three major drought cycles and its ultimate collapse. Simulating the model through time shows the spread of human settlement across the landscape. A number of functions for rainfall, net primary productivity, and agricultural suitability are calculated by the cell-based landscape, and changes based on assumptions about climate cycles that influence rainfall. Demographics interacts with spatial data to grow agricultural crops and drive migration and further settlement. Settlements are linked via a trade network, and the provision of ecosystem services, agriculture, and trade combine to provide overall human well-being. The system is then simulated through time and under comparative scenarios to examine under what conditions the system maintains sustainability, or in turn collapses or re-organizes. The model is evaluated based on its ability to generate outcomes consistent with the body of archeological evidence, in this case the ability to generate the regional settlement pattern of lowland Mayan cities, the location of cross-Yucatan peninsular trade routes via El Mirador, Tikal and Calakmul, and the ascendency of coastal cities in the post-classic period. The model allows the investigation of a range of scenarios including: altering the frequency and severity of droughts, the sophistication of trade technology by land, canoe and marine routes, and the impacts of random shocks such as volcanic eruptions

IHOPE will encourage the development, testing and utilization of other integrated, dynamic models to help us better understand the past as a means to creating a sustainable and desirable future. By building such multi-scalar models of the dynamics of different kinds of societies, and comparing them from the perspective of their structuration as well as evolution over time in different environments, we will gain a much improved insight in scales of socio-environmental dynamics that we have thus far not been able to grasp, and thus to improve our decisionmaking about our future, which is seeing currently such dramatic changes in the breadths of the temporal and spatial scales involved.

For example, The Roman Period as described above offers a number of advantages for modeling, as a number of well-informed datasets exist, including information on regional differences across the area of the Empire. It will therefore constitute one of the ongoing case studies for the development and implementation of integrated IHOPE models. The model will be used to further test the hypotheses developed during data collection and to examine the impact of population migration on the landscape. We are also developing a collaboration with the ARVE (Atmosphere Regolith Vegetation) modeling group led by Jed Kaplan at the École Polytechnique Fédérale de Lausanne. This group has developed a model of land use change in response to changing population pressure, and have used this to quantify the subsequent effects on the carbon cycle. As this currently relies on imposed population growth, we intend to couple this with the demographic part of the IHOPE mode, to allow us to dynamically estimate human impact on ecosystem services.

The modeling will extend to other case studies, and applications during the next phase of work. 


\section{Related projects}

Several ongoing related projects connect with and support the IHOPE initiative. These include:

\section{IGBP-PAGES (Past Global Changes) Focus 4 'Past Human-Climate-Ecosystem- Interactions}

IGBP-PAGES (http://www.pages-igbp.org/science/focus4.html) is a co-sponsoring project of IHOPE. An annual IHOPE report is presented annually to the PAGES SSC. The Focus 4 programme draws together paleoenvironmentalists who reconstruct environmental changes under several themes: Biodiversity, Soil and Sediments, Carbon, Water and Regional Integration. The last of these engages most directly with IHOPE through attempts to integrate archival records of all kinds for socio-ecological systems at regional scales. The first meeting took place 23-25 $5^{\text {th }}$ September 2010 in Southampton, UK with the aim of producing a protocol for the collation and analysis of archival records in developing evolutionary perspectives on modern socio-ecological systems.

\section{The Urban Mind}

This project studies urban resilience across the world and over the long term, from the development of urbanism 10,000 years ago until modern times (http://www.arkeologi.uu.se/Forskning/Projekt/Urban_Mind/Introduction/). It involves researchers in the humanities and the social and biophysical sciences from various institutes in Sweden, the United Kingdom, Germany, Turkey, Zimbabwe and South Africa. The development of urbanism is a global phenomenon that takes radically different forms in different times and places, with widely varying consequences. Ongoing studies address cognitive aspects of urbanism and climate change in Africa, Eurasia and the Americas. This project has been funded in a targeted grant from MISTRA.

\section{The archaeology of African urbanism}

Africa has the longest record of human occupation of any continent. The urban past of Africa is complex and multifacetted and has a deep time depth of at least 6000 years. It is characterized by variety of location, form and organization. Recent overviews have grappled with problems of definition of the "urban" and "non-urban" function and specialization and these will be critically reviewed. African urbanism is analyzed in terms of multi-scalar regional and landscape perspectives highlighting the interactions between climate change and ecosystem services, local and inter-regional production and exchange, as well as governance and ideology. A thematic approach of these issues by region is undertaken for North West Central East and southern Africa and Madagascar based on the concept of energy regimes. The temporal scope is broad; consideration is also given to certain Mid Holocene hunter-forager settlement systems that are normally excluded from considerations of urban complexity. Further crucial challenges of integrating modern urban development into the analytical frame defined by the archaeological record will also be considered. Key Faculty: Paul Sinclair (Uppsala University) Innocent Pikirayi (Pretoria University). Seed funding for new planning initiatives has been provided by STIAS (the Wallenebrg Institute of Advanced Stuies) Stellenbosch South Africa and the Swedish Bank Tercentenary Foundation.

\section{Expertise for the Future}

This is a thematic project that cuts across disciplines in examining the history of the idea of environmental prediction and the reception of both optimistic and pessimistic predictions by societies. The period studied begins in the sixteenth century; predictions range from personal observation to interpretation of longitudinal data trends (prices, demographic data, meteorological records) as statistical modeling becomes increasingly important. This crosscutting comparative methodology can be applied to all case studies; it provides a way to examine IHOPE itself and its role in today's politics of science. This project has funding from the Leverhulme Trust, the Center for History and Economics, Harvard University, the Australian Museum of Natural History, and the SRC.

\section{The CLIO-INFRA Project}

This project (http://www.clio-infra.eu) aims to create reliable global datasets of the most relevant indicators of economic performance and its causes for the past 500 years. It adresses the topic of global inequality, the increasing divergence between rich and poor countries, which is one of most pressing concerns of our time and the near future. 


\section{The Big History Project}

This project (http://www.bighistoryproject.com/), initiated by David Christian, weaves evidence and insights from many scientific and historical disciplines across 13.7 billion years into a single, accessible origin story. One that explores who we are, how we got here, how we are connected to everything around us, and where we may be heading. The concept arose from a desire to go beyond the specialized and self-contained fields that emerged in the 20th century and grasp history as a whole, looking for common themes across the entire time scale of history. The Big History Project LLC (BHP) is an organization focused on bringing this unique learning experience to life for high school students.

\section{Conclusions}

Many contemporary societal challenges manifest themselves in the domain of human-environment interactions. There is a growing recognition that responses to these challenges formulated within current disciplinary boundaries, in isolation from their wider contexts, cannot adequately address them. We need an integrated, trans-disciplinary synthesis that allows for a holistic approach, and, above all, a much longer time perspective. That is the rational and approach of the IHOPE initiative. This approach promises to yield new understandings of the relationship between the past, present and possible futures of our integrated human-environment system. IHOPE embodies a unique new focus of our historical efforts on the future, rather than the past, concentrated on learning about future possibilities from the development of a science of the past. A growing worldwide community of trans-disciplinary scholars is forming around building this Integrated History and future of People on Earth. The initiative has already stimulated significant new research and a large number of publications have already resulted, directly or indirectly, connected with the major themes of IHOPE ${ }^{15-71}$. The activity has also become a major focus within the global change community. Building integrated models of past human societies and their interactions with their environments yields new insights into those interactions and can help to create a more sustainable and desirable future.

\section{Acknowledgements}

The IHOPE initiative has received support from several sources, including: the National Center for Ecological Analysis and Synthesis (NCEAS), the Stockholm Resilience Center, the QUEST project at the University of Bristol, the University of Uppsala, Arizona State University, the Institute for Sustainable Solutions at Portland State University, the Australian National University, the Dahlem Foundation, the National Center for Atmospheric Research (NCAR), and the Pacific Northwest National Laboratory (PNRL). We also thank two anonymous reviewers for their helpful comments on earlier drafts.

\section{References Cited}

${ }^{1}$ Costanza, R., L.J. Graumlich, W. Steffen (eds.) 2007 Sustainability or Collapse? An Integrated History and future Of People on Earth Cambridge, Mass: MIT Press (Dahlem Workshop Reports \# 96).

${ }^{2}$ Costanza, R. L. Graumlich, W. Steffen, C. Crumley, J. Dearing, K. Hibbard, R. Leemans, C. Redman, and D. Schimel. 2007. Sustainability or Collapse: What Can We Learn from Integrating the History of Humans and the Rest of Nature? Ambio 36:522-527

${ }^{3}$ Hibbard, K. A., R. Costanza, C. Crumley, S. van der Leeuw, S. Aulenbach, J. Dearing, J. Morais, W. Steffen and Y. Yasuda. 2010. Developing an Integrated History and Future of People on Earth 
(IHOPE): Research Plan. IGBP Report No. 59. IGBP Secretariat, Stockholm, Sweden. 40pp. http://www.aimes.ucar.edu/ihope/documents/

${ }^{4}$ Ramankutty, N. and J. A. Foley. 1999. Estimating historical changes in global land cover: Croplands from 1700 to 1992. Global Biogeochemical Cycles, 13:997-1027.

${ }^{5}$ Pongratz, J., Reick, C., Raddatz, T. \& Claussen, M. 2008. A reconstruction of global agricultural areas and land cover for the last millennium. Global Biogeochemical Cycles, 22(3). doi: $10.1029 / 2007$ GB003153

${ }^{6}$ Kaplan, J. O., Krumhardt, K. M., Ellis, E. C., Ruddiman, W. F., Lemmen, C. \& Klein Goldewijk, K. 2010. Holocene carbon emissions as a result of anthropogenic land cover change. The Holocene, 20, doi:10.1177/0959683610386983

${ }^{7}$ Hurtt, G. C., Chini, L. P., Frolking, S., Betts, R., Feddema, J. J., Fischer, G., Hibbard, K. A., Janetos, A. C., Jones, C., Klein Goldewijk, K., Kindermann, G., Kinoshita, T., Riahi, K., Shevliakova, E., Smith, S., Stehfest, E., Thomson, A., Thornton, P., van Vuuren, D. \& Wang, Y. P. 2011. Harmonization of land-use scenarios for the period 1500-2100: 600 years of global gridded annual landuse transitions, wood harvest, and resulting secondary lands. Climatic Change. 109:117-161. doi:10.1007/s10584-011-0153-2.

${ }^{8}$ Klein Goldewijk, K., Beusen, A., van Drecht, G. \& de Vos, M. 2011. The HYDE 3.1 spatially explicit database of human induced land use change over the past 12,000 years. Global Ecology and Biogeography, 20(1), doi: 10.1111/j.1466-8238.2010.00587.x.

${ }^{9}$ Tainter, J., 1988 The Collapse of Ancient Societies, Cambridge: Cambridge University Press

${ }^{10}$ Costanza, R. 1987. Social traps and environmental policy. BioScience 37:407-412.

${ }^{11}$ Ostrom, E. 1990. Governing the Commons: The Evolution of Institutions for Collective Action. Cambridge University Press.

${ }^{12}$ Crumley, C., 2010, The Archaeology of Global Environmental Change. Humans and the Environment: new Archaeological Perspectives for the 21st Century. Matthew Davies and Freda Nkirote (eds.) Oxford: Oxford University Press.

${ }^{13}$ Williams, A., S. Ulm, I.D. Goodwin and M. Smith. 2010. Hunter-Gatherer Response to Late Holocene Climatic Variability in Northern and Central Australia. Journal of Quaternary Science 25: 831838.

${ }^{14}$ Robin, L. et al. (eds). 2009. The Pulse. Life in a land of uncertain extremes. National Museum of Australia press

${ }^{15}$ Anderies, J.M., M. Hegmon 2011. Robustness, and Resilience Across Scales: Migration and Resource Degradation in the Prehistoric Southwest US, Ecology and Society. 16(2): 22

${ }^{16}$ Barthel, S. et al. (in press), Urban Gardens-Pockets of social-ecological Memory. In (eds) Tidball, KG and ME Krasny (eds.) (expected 2011) Greening in the Red Zone: Disaster, Resilience, and Community Greening. Springer-Verlag

${ }^{17}$ Barthel, S. et al., 2010, Social-ecological Memory in Urban Gardens. Retaining the capacity for management of ecosystem services. Global Environmental Change, 20(2): 255-256

${ }^{18}$ Barthel, S., Sörlin, S., Ljungkvist, J. 2011. Urban Anthropocene: Innovative Memory for Resilient Cities With Echoes from Ancient Constantinople. In (eds), Paul Sinclair, Frands Herschend, Chrstian Isendahl and Gullög Nordquist. The Urban Mind, cultural and environmental dynamics. (Studies in Global Archaeology, 15) Uppsala: Uppsala University Press.

${ }^{19}$ Beddoe, R., R. Costanza, J. Farley, E. Garza, J. Kent, I. Kubiszewski, L. Martinez, T. McCowen, K. Murphy, N. Myers, Z. Ogden, K. Stapleton, and J. Woodward. 2009. Overcoming Systemic Roadblocks to Sustainability: the evolutionary redesign of worldviews, institutions and technologies. Proceedings of the National Academy of Sciences 106:2483-2489.

${ }^{20}$ Berger, J.F., L. Nuninger \& S.E. van der Leeuw 2007 "Modeling the Role of Resilience in SocioEnvironmental Co-evolution: The Middle Rhône Valley between 1000 b.c. and a.d. 1000”, in 
The Model-Based Archaeology of Socio-natural Systems (T. Kohler \& S.E. van der Leeuw, eds.), pp 41-60 Santa Fe, NM: School of Advanced Research.

${ }^{21}$ Boyle, J.F., Gaillard M.-J., Kaplan, J.O. and Dearing, J.A. 2011, Modelling prehistoric land use and carbon budgets: a critical review. The Holocene. 21:715-722 DOI: 10.1177/0959683610386984

${ }^{22}$ Cornell, S., R. Costanza, S. Sörlin, and S. van der Leeuw, 2010, Developing a systematic "science of the past" to create our future. Global Environmental Change, 20:426-427.

${ }^{23}$ Crook D.C., Elvin M, Jones R.J., Shen Ji and Dearing J.A. 2008. The History of Irrigation and Water Control in China's Erhai Catchment: Mitigation and Adaptation to Environmental Change. In Wiegandt, E (ed) Mountains:Sources of Water, Sources of Knowledge. Series: Advances in Global Change Research vol. 31. Kluwer Publications. 21-42, pp. 382 10.1007/978-1-40206748-8_3

${ }^{24}$ Crumley, C., 2010, The Archaeology of Global Environmental Change. Humans and the Environment: new Archaeological Perspectives for the 21st Century. Matthew Davies and Freda Nkirote (eds.) Oxford: Oxford University Press.

${ }^{25}$ Dai X., Yu L., Dearing, J.A., Zhang W., Shi Y., Zhang F., Gu C., Boyle, J.F, Coulthard, T.J. and Foster, G.C. 2009. The recent history of hydro-geomorphic processes in the upper Hangbu river system, Anhui Province, China. Geomorphology 106, 363-375. Doi: 10.1016/j.geomorph.2008.11.016

${ }^{26}$ Dearing, J.A. 2008. Landscape change and resilience theory: a palaeoenvironmental assessment from Yunnan, SW China. The Holocene 18:117-127.

${ }^{27}$ Dearing, J.A. in press Approaches to understanding long term human-environment interactions - past, present and future. Chapter in Matthews, J.A. (ed) Handbook of Environmental Change, Sage.

${ }^{28}$ Dearing, J.A., Battarbee, R.W., Bhagwat, S., Costanza, R., Edwards, M.E., Gell, P., Hibbard, K.A., Kiefer, T., Marchant, R., de Morais, J.M.F., Sugita, S.,Umer, M., van der Leeuw, S., Wanner, H. and Willis, K.J. 2009 Long term human-environment interactions, Scoping paper for IPCC AR5 Working Group II produced by IGBP-PAGES-PHAROS and IGBP-IHDP-IHOPE research communities (unpublished report).

${ }^{29}$ Dearing, J.A., Braimoh, A.K., Reenberg, A., Turner, B.L. II., and van der Leeuw, S.E. 2010. Complex land systems: the need for long time perspectives in order to assess their future. Ecology and Society $15(4): 21$

${ }^{30}$ Dearing, J.A., Jones, R.T., Shen, J., Yang, X., Boyle, J.F., Foster, G.C., Crook, D.S. and Elvin, M.J.D. 2008. Using multiple archives to understand past and present climate-human-environment interactions: the lake Erhai catchment, Yunnan Province, China (invited Deevey and Frey Review Article), J. Paleolimnology 40:3-31 . 10.1007/s10933-007-9182-2.

${ }^{31}$ Dearing, J.A., L.J. Graumlich, R.H. Grove, A. Grübler, H. Haberl, F. Hole, C. Pfister, S.E. van der Leeuw 2008. "Group Report: Integrating Socioenvironmental Interactions over Centennial Timescales - Needs and Issues". In: Sustainability or Collapse? (R. Costanza, L.J. Graumlich, W. Steffen, eds.), pp. 243-274. Cambridge, Mass: MIT Press (Dahlem Workshop Reports)

${ }^{32}$ Foster, G.C., Chiverrell, R.C., Harvey, A.M., Dearing, J.A. and Dunsford, H. Lake catchment hydrogeomorphological responses to environmental change in the Southern Uplands of Scotland, The Holocene. 18:935. DOI: 10.1177/0959683608091799

${ }^{33}$ Gaillard, M.-J., Sugita, S., Bunting, J., Dearing, J.A. and Bittmann, F. (eds) 2008. Human impact on terrestrial ecosystems, pollen calibration and quantitative reconstruction of past land cover. Vegetation History and Archaeobotany 17: 415-615. Doi: 10.1007/s00334-008-0170-x

${ }^{34}$ Hegmon, M., M. Peeples, A. Kinzig, S. Kulow, C. Meagan, and M. Nelson. 2012. The Rigidity Trap and Social Transformations: Long Term Perspectives from the Archaeology of the U.S. Southwest, Ecology and Society (in press) 
${ }^{35}$ Jackson, S.T. 2012. Conservation and resource management in a changing world: Extending historical range-of-variability beyond the baseline. J.A. Wiens, G.D. Hayward, H.D. Safford, and C. Giffen (editors). Historical Environmental Variation in Conservation and Natural Resource Management. Wiley-Blackwell.

${ }^{36}$ Janssen, M.A., 2010, Population Aggregation in Ancient Arid Environments, Ecology and Society 15 (2): 19

${ }^{37}$ Kohler, T. \& S.E. van der Leeuw, 2007, "Historical Socionatural Systems and Models: An Introduction to the Volume" in The Model-Based Archaeology of Socio-natural Systems (T. Kohler and S. E. van der Leeuw, eds.), pp. 1-12, Santa Fe: School of Advanced Research.

${ }^{38}$ Ljungkvist, J., S. Barthel, S. Sörlin, S. Finnveden, (accepted), Lessons for a Sustainable Urban Anthropocene from the Metabolic History of Constantinople In (eds.), P. Sinclair, F. Herschend, C. Isendahl and G. Nordquist. The Urban Mind, cultural and environmental dynamics. (Studies in Global Archaeology, 15), Uppsala: Uppsala University Press.

${ }^{39}$ Miller, F., H. Osbahr, E. Boyd, F. Thomalla, S. Bharwani, G. Ziervogel, B. Walker, J. Birkmann, S.E. van der Leeuw, J. Rockström, J. Hinkel, T. E. Downing, C. Folke, D. R. Nelson, 2012, "Resilience and Vulnerability: Complementary or conflicting concepts?", Revised version accepted by Ecology and Society,

${ }^{40}$ Nelson, M., K. Kintigh, D. R. Abbott, J. M. Anderies, 2012. Archaeology's long-term perspective on irrigation infrastructure and vulnerability, Ecology and Society (in press)

${ }^{41}$ Nelson, M., M. Hegmon, S. Kulow, M. Peeples, K. Kintigh, A. Kinzig 2011. Resisting Diversity: A Long-term Archaeological Study, Ecology and Society 16(1):25

${ }^{42}$ Redman C.L., C.L. Crumley, F. Hassan, K. F. Hole, F. Riedel, J.A. Tainter, P. Turchin, V.L. Scarborough, and Y. Yasuda. 2007. "Group Report: Millennial Perspectives on the Dynamic Interaction of Climate, People, and Resources." In Sustainability or Collapse? Integrated History and Future of People on Earth (IHOPE), edited by R. Costanza, L. Graumlich, and W. Steffen, pp. 115-148. Dahlem Workshop Report 96R. The MIT Press, Cambridge, MA.

${ }^{43}$ Robin, L. and Steffen, W. 2007. History for the Anthropocene. History Compass, 5: 10.1111/j.14780542.2007.00459.x

${ }^{44}$ Robin, L., S. Sörlin and P. Warde, (eds). 2013. The Future of Nature: Documents of Global Change. Yale University Press, (in press).

${ }^{45}$ Rockström, J., Steffen, W., Noone, K., Persson, Å, Chapin, III, F.S., Lambin, E.F., Lenton, T.M., Scheffer, M., Folke, C., Schellnhuber, H.J., Nykvist, B., de Wit, C.A., Hughes, T., van der Leeuw, S., Rodhe, H., Sörlin, S., Snyder, P.K., Costanza, R., Svedin, U., Falkenmark, M., Karlberg, L., Corell, R.W., Fabry, V.J., Hansen, J., Walker, B., Liverman, D., Richardson, K., Crutzen, P. and Foley, J.A. 2009. Planetary Boundaries: Exploring the Safe Operating Space for Humanity. Ecology and Society 14 (2): 32. [online] URL: http://www.ecologyandsociety.org/vol14/iss2/art32/

${ }^{46}$ Rockström, J., Steffen, W., Noone, K., Persson, Å, Chapin, III, F.S., Lambin, E.F., Lenton, T.M., Scheffer, M., Folke, C., Schellnhuber, H.J., Nykvist, B., de Wit, C.A., Hughes, T., van der Leeuw, S., Rodhe, H., Sörlin, S., Snyder, P.K., Costanza, R., Svedin, U., Falkenmark, M., Karlberg, L., Corell, R.W., Fabry, V.J., Hansen, J., Walker, B., Liverman, D., Richardson, K., Crutzen, P. and Foley, J.A. 2009. A safe operating space for humanity. Nature 461: 472-475.

${ }^{47}$ Scarborough, V.L. 2009. "Beyond Sustainability: Managed Wetlands and Water Harvesting in Ancient Mesoamerica." In The Archaeology of Environmental Change: Socionatural Legacies of Degradation and Resilience, edited by C.T. Fisher, J.B. Hill, and G.M. Feinman, 62-82. University of Arizona Press, Tucson.

${ }^{48}$ Scarborough, V.L. (editor) 2012. Water and Humanity: A Historical Overview (History of Water and Civilization Book Series, Volume VII). UNESCO, Paris. (In Press). 
${ }^{49}$ Scarborough, V.L. 2003. "How to Interpret an Ancient Landscape." Proceedings of the National Academy of Sciences 100:4366-4368.

${ }^{50}$ Scarborough, V.L. 2007 "Colonizing a Landscape: Water and Wetlands in Ancient Mesoamerica." In The Political Economy of Ancient Mesoamerica: Transformations during the Formative and Classic Periods, edited by V.L. Scarborough and J. Clark, 163-174. University of New Mexico Press, Albuquerque.

${ }^{51}$ Scarborough, V.L. 2007 "The Rise and Fall of the Ancient Maya: A Case Study in Political Ecology." In Sustainability or Collapse? Integrated History and Future of People on Earth (IHOPE), edited by R. Costanza, L. Gramlich and W. Steffen, pp. 51-60. Dahlem Workshop Report 96R. The MIT Press, Cambridge, MA.

${ }^{52}$ Scarborough, V.L. 2008. "Rate and Process of Societal Change in Semitropical Settings: The Ancient Maya and the Living Balinese." Quaternary International 184:24-40.

${ }^{53}$ Scarborough, V.L. 2010. "The Archaeology of Sustainability: Mesoamerica (invited). Ancient Mesoamerica 20:197-203.

${ }^{54}$ Scarborough, V.L. and Fred Valdez. 2009 "An Alternative Order: The Dualistic Economies of the Ancient Maya." Latin American Antiquity 20:207-27.

${ }^{55}$ Scarborough, V.L. and W. Burnside. 2010 Global Change: Mapping Culture onto Climate. In Climate Crises in the Human Past, edited by A.B. Mainwaring, R. Giegengack, and C. Vita-Finzi, pp. 175187. American Philosophical Society and Lighting Rod Press, volume 6. Philadelphia.

${ }^{56}$ Scarborough, V.L. W. Burnside. 2010. Complexity and Sustainability: Perspectives from the Ancient Maya and the Modern Balinese. American Antiquity 75(2):327-63.

${ }^{57}$ Shen, Z., Bloemendal, J., Mauz, B., Chiverrell, R.C., Dearing, J.A. and Liu, Q. 2008. Environmental magnetism and optical luminescence chronology of Lateglacial and Postglacial sediments from Crummock Water, English Lake District. The Holocene 18:129-140.

${ }^{58}$ Sinclair, P., G. Nordquist, F. Herschend \& C. Isendahl (eds), 2010 The Urban Mind: cultural and environmental dynamics, Studies in Global Archaeology 15, Uppsala University.

${ }^{59}$ Sörlin, S., et al. (in press) Environmental futures, predictions and precautions for global change thinking, New Haven:Yale University Press

${ }^{60}$ Spielmann, K., M. Nelson, S. Ingram, and M. Peeples. 2011. Sustainable Small-Scale Agriculture in Semi-Arid Environments. Ecology and Society 16(1):26

${ }^{61}$ Steffen, W. 2008. Looking back to the future. Ambio 37: 507-513

${ }^{62}$ Steffen, W., Crutzen, P.J. and McNeill, J.R. 2007. The Anthropocene: Are humans now overwhelming the great forces of Nature? Ambio 36:614-621.

${ }^{63}$ van der Leeuw, S., R. Costanza, S. Aulenbach, S. Brewer, M. Burek, S. Cornell, C. Crumley, J. A. Dearing, C. Downy, L. J. Graumlich, S. Heckbert, M. Hegmon, K. Hibbard, S. T. Jackson, I. Kubiszewski, P. Sinclair, S. Sörlin, and W. Steffen. 2011. Toward an Integrated History to Guide the Future. Ecology and Society. 16(4): 2. http://dx.doi.org/10.5751/ES-04341-160402

${ }^{64}$ van der Leeuw, S.E., 2007a, "Including Humans in Earth System Modelling”, Global Change Newsletter 69 (Guest editorial), May 2007.

${ }^{65}$ van der Leeuw, S.E., 2007b, Information Processing and Its Role in the Rise of the European World System. In: Sustainability or Collapse? (R. Costanza, L.J. Graumlich, W. Steffen, eds.), pp. 213241. Cambridge, Mass: MIT Press (Dahlem Workshop Reports).

${ }^{66}$ van der Leeuw, S.E., 2008, Climate and Society: Lessons from the past 10,000 years, Ambio 37: 476482.

${ }^{67}$ van der Leeuw, S.E., 2009. What is an 'Environmental Crisis' to an Archaeologist. pp. 40-61 in: The archaeology of environmental change - Socio-natural legacies of degradation and resilience (C. Fisher, B. Hill \& G. Feinman, eds.), , Tucson: University of Arizona Press. 
${ }^{68}$ van der Leeuw, S.E., D. Lane, D. W. Read, 2009 "The long-term evolution of social organization", Chapter 3 in: D. Lane, D. Pumain, S. E, van der Leeuw and G. West (eds.) Complexity Perspectives on Innovation and Social Change, pp. 85-115, Berlin: Springer (Methodos series)

${ }^{69}$ Welsh, K.E., Dearing, J.A., Chiverrell, R.C., Coulthard, T.J. 2009.Testing a cellular modelling approach to simulating late Holocene sediment and water transfer from catchment to lake in the French Alps since 1826. The Holocene 19:783-796.

${ }^{70}$ Yan Z., Gu H., Dai Y., Wu X., Dearing, J.A., Zhang, W. and Yu L. 2009. Population, land use and environmental impacts in Shucheng County, Anhui Province, China during the Ming and Qing dynasties. Environment and History 15:61-78 doi:10.3197/096734009X404662

${ }^{71}$ Zalasiewicz, J., Williams, M., Steffen, W. and Crutzen, P. 2010. The new world of the Anthropocene. Environmental Science \& Technology, 44:2228-2231 doi: 10.1021/es903118j 